\title{
ANALISIS MUTU KERANG DARAH (Anadara granosa) ASAP YANG DIKEMAS VAKUM DAN NON VAKUM PADA PENYIMPANAN SUHU RUANG
}

Quality Analysis of Smoked Cockle Shells (Anadara granosa) with vacuum and non vacuum packaging techniques in room temperature

\author{
Yoni ${ }^{*}{ }^{*}$, Kobajashi T. Isamu ${ }^{1}$, Sri Rejeki ${ }^{2}$ \\ 1Jurusan Teknologi Hasil Perikanan, Fakultas Perikanan dan Ilmu Kelautan Universitas Halu Oleo, Kendari, \\ Sulawesi Tenggara, Indonesia \\ 2Jurusan IImu dan Teknologi Pangan, Fakultas Pertanian Universitas Halu Oleo, Kendari, Sulawesi Tenggara, \\ Indonesia \\ *Email korespondensi: yonithp@gmail.com (Telp: +6282325655402) \\ Diterima: 10 Januari/ Disetujui 15 Maret 2020
}

Cara sitasi: Yoni, Isamu KT, Rejeki S. 2020. Analisis mutu kerang darah (Anadara granosa) asap yang dikemas vakum dan non vakum pada penyimpanan suhu ruang. Jurnal Fish Protech. 3(1):104-112.

\section{ABSTRACT}

This study aims to determine the effect of packaging factors and storage time on organoleptic values, total bacterial counts and chemical analysis of smoked cockle shells. The characteristics tested were sensory, water content, total bacterial count (TPC) and the value of the PAH compound (Polycyclic Aromatic Hydrocarbon) smoked cockle shells. This study uses a Completely Randomized Design (CRD) consisting of 6 treatments V1L1 (vacuum packaging technique, 2 days storage time), V2L1 (non vacuum packaging technique, 2 days storage time), V1L2 (vacuum packaging technique, length of storage time 4 days), V2L2 (non-vacuum packaging technique, 4 days storage time), V1L3 (vacuum packaging technique, 6 days storage time), V2L3 (non-vacuum packaging technique, 6 days storage time) and replications three times. Data from observations were analyzed using ANOVA (Analysis of Variance) at a level of $95 \%$, if there is a significant difference $(P>0.05)$ then a further test was performed with a DMRT (Duncan Multiple Range Test) test at a 95\% significance level. The results obtained showed that the packaging technique and the storage time of smoked cockle shells had a very significant effect on the sensory value which included appearance, aroma, and taste, but the texture sensory had a real effect and on the fungus sensory had no significant effect. The best results for sensory assessment are in the V1L1 treatment which has a value of appearance 7.62, aroma 7.64, taste 7.93 and texture 7.42. The best treatment on the total number of bacteria (TPC) showed the best value, namely V1L1 treatment with a value of $1.1 \times 10^{3} \mathrm{CFU} / \mathrm{ml}$. The best treatment in chemical tests is in the treatment V1L1 with a moisture content value of 45.26\%, while for the value of the PAH compound (Polycyclic Aromatic Hydrocarbon) the value is the same, $<0.51 \mathrm{ppm}$ both for vacuum and non vacuum packaging techniques.

Keywords: Cockle shells (Anadara granosa). Smoke, packaging, storage, room temperature

\section{ABSTRAK}

Penelitian ini bertujuan Untuk mengetahui pengaruh faktor kemasan dan lama penyimpanan terhadap nilai organoleptik, jumlah total bakteri dan analisis kimia kerang darah asap. Karakteristik yang diuji yaitu sensori, kandungan kadar air, jumlah total bakteri (TPC) dan nilai senyawa PAH (Polycyclic Aromatic Hydrocarbon) kerang darah asap. Penelitian ini menggunakan Rancangan Acak Lengkap (RAL) yang terdiri dari 6 perlakuan V1L1 (Teknik pengemasan vakum, lama waktu penyimpanan 2 hari), V2L1 (Teknik penemasan non vakum, lama waktu penyimpanan 2 hari), V1L2 (Teknik penemasan vakum, lama waktu penyimpanan 4 hari), V2L2 (Teknik penemasan non vakum, lama waktu penyimpanan 4 hari), V1L3 (Teknik penemasan vakum, lama waktu penyimpanan 6 hari),V2L3 (Teknik penemasan non vakum, lama waktu penyimpanan 6 hari) dan ulangan sebanyak tiga kali. Data hasil pengamatan dianalisa menggunakan ANOVA (Analysis of Variance) pada taraf $95 \%$, apabila terdapat beda nyata $(P>0,05)$ maka dilakukan uji lanjut dengan uji DMRT (Duncan Multiple Range Test) pada taraf nyata 95\%. Hasil penelitian yang diperoleh menunjukkan bahwa teknik pengemasan dan waktu penyimpanan kerang darah asap memberikan pengaruh sangat nyata terhadap nilai sensori yang meliputi kenampakan, aroma, dan rasa, tetapi pada sensori tekstur memberikan pengaruh nyata dan pada sensori jamur berpengaruh tidak nyata. Hasil terbaik untuk penilaian sensori terdapat pada perlakuan V1L1 dimana 
memiliki nilai kenampakan 7,62, aroma 7,64, rasa 7,93 dan tekstur 7,42. Perlakuan terbaik pada jumlah total bakteri (TPC) menunjukkan nilai terbaik yaitu perlakuan V1L1 dengan nilai $1,1 \times 10^{3} \mathrm{CFU} / \mathrm{ml}$. Perlakuan terbaik pada uji kimia terdapat pada perlakuan V1L1 dengan nilai kadar air 45,26\%, sedangkan untuk nilai senyawa PAH (Polycyclic Aromatic Hydrocarbon) nilainya sama yaitu $<0,51$ ppm baik yang teknik pengemasan vakum maupun non vakum.

Kata kunci: kerang darah (Anadara granosa). pengasapan, pengemasan, penyimpanan, suhu ruang

\section{PENDAHULUAN}

Indonesia memiliki potensi sumber daya alam yang melimpah. Berbagai upaya dan cara dilakukan oleh masyarakat dan negara untuk memanfaatkannya. Sumber daya alam merupakan modal utama bagi suatu negara untuk kesejahteraan rakyat. Sulawesi Tenggara mempunyai potensi keanekaragaman hayati perairan yang cukup melimpah. Salah satu diantaranya adalah kerang darah (Anadara granosa). Menurut Badan Pusat Statistik RI tahun 2017 nilai produksi perikanan laut yang dijual di TPI, mencapai 9.937 juta ton. Data tersebut termaksud produksi kerang darah yaitu 5.337.537 ton. Menurut Badan Pusat Statistik Sultra 2017 produksi perikanan tangkap mencapai 203.872 ton. Sedangkan menurut Badan Pusat Statistik Kota Kendari 2017 produksi pendaratan ikan menurut jenisnya di Kota Kendari mencapai 34.013 ton. Untuk jenis ikan lain-lain yang termaksut jenis mollusca mencapai 5.483 ton.

Kerang darah adalah jenis kerang yang umum bagi masyarakat, pemanfaatannya secara umum adalah sebagai bahan konsumsi. Kerang darah memiliki banyak kandungan yang dibutuhkan oleh tubuh sebagai sumber vitamin. Berdasarkan hasil penelitian (Ferial et al., 2011) kerang darah dapat dimanfaatkan sebagai terapi utuk perbaikan kualitas spermatozoid pada manusia. Dijelaskan bahwa kerang darah mampu memperbaiki volume, likuefaksi, viskositas, $\mathrm{pH}$, konsentrasi, motilitas, jumlah dan viabilitas dan aglutinasi spermatozoid pada manusia. Selain sebagai bahan konsusmsi dan obat-obatan, limbah kerang berupa cangkang masih dapat dimanfaatkan sebagai nilai ekonomis, yaitu pemanfaatan cangkang kerang sebagai bahan kerajinan hias.
Pengasapan merupakan salah satu cara pongolahan pada kerang yang berfungsi untuk mengawetkan serta memberi aroma dengan cita rasa yang khas pada kerang. Sulawesi Tenggara khususnya di Wilayah Kota Kendari terdapat beberapa jenis kerang tetapi yang lebih dikenal dengan sebutan Bakala (kerang darah) jenis Bivalfia ini sangat potensial sehingga dapat dikembangkan lagi menjadi produk-produk diversifikasi.

Salah satu usaha yang dilakukan dalam peningkatan mutu dan nilai ekonomi suatu produk adalah dengan pengemasan yang baik, a man dan efisien. Pengemasan vakum adalah sistem pengemasan hampa udara dimana tekanannya kurang dari $1 \mathrm{~atm}$ dengan cara mengeluarkan udara kemasan sehingga memperpanjang umur simpan. Proses pengemasan vakum ini dilakukan dengan cara memasukan produk kedalam kemasan plastik yang diikuti dengan pengontrolan udara menggunakan mesin pengemas vakum. Kemudian ditutup dan disegel, dengan ketidak adaan udara dalam kemasan, maka kerusakan akibat oksidasi dapat dihilangkan sehingga kesegaran produk yang dikemas akan lebih bertahan 3-5 kali lebih lama dari pada produk yang dikemas dengan pengemasan non vakum (Jay, 1996).

\section{METODE PENELITIAN}

\section{Alat dan Bahan}

Alat yang digunakan pada penelitian ini Alat yang digunakan untuk mengemas vakum, mesin pengemas vakum. Alat yang digunakan untuk pengujian TPC penghitung koloni "hand totally counter", bunsen, botol media, gunting, pinset autocla ve, refrigerator, dan freezer. Alat yang digunakan 
untuk analisis kadar air adalah oven listrik, cawan alumunium, gegep, labu kjeldahl $300 \mathrm{~mL}$, Buret skala $0,1 \mathrm{~mL}$.

Bahan yang digunakan terdiri atas bahan utama dan bahan pendukung. Bahan utama adalah daging kerang darah segar. Bahan pendukung adalah tempurung kelapa, sabut kelapa, untuk bahan

\section{Rancangan Penelitian}

Penelitian ini RAL yang terdiri dari enam perlakuan yaitu teknik pengemasan vakum lama penyimpanan 2 (V1L1),4 (V1L2) dan 6 (V1L3) hari.te knik pengemasan non vakum lama waktu penyimpanan 2 (V2L1),4 (V2L2) dan 6 (V2L3) hari Masing-masing perlakuan dilakukan tiga kali ulangan, sehingga diperoleh jumlah satuan percobaan sebanyak 18 unit.

\section{Prosedur Penelitian}

Prosedur penelitian ini dapat dilihat langka-langka sebagai berikut : Kerang darah yang akan digunakan dalam penelitian ini diambil langsung dari pedagang kerang yang berada disekitaran jembatan Tripping By pass Kota Kendari. Sedangkan bahan pengasapan tempurung dan sabut kelapa yang digunakan sebagai bahan pengasap diperoleh dari pasar PKL Lawata Kota Kendari dan bahan pengemasan Plastik Polyetilen diperoleh di toko pandan.

Proses pembuatan kerang darah asap dengan metode pengasapan tradisional dengan menggunakan bahan pengasap sebanyak $3 \mathrm{~kg}$ dengan menggunakan bahan pengasap tempurung kelapa $1,5 \mathrm{~kg}$ dan sabut kelapa $1,5 \mathrm{~kg}$. Adapun prosesnya adalah kerang dicuci bersih untuk menghilangkan lumpur dan kotoran lainnya, kerang pengasap dan garam untuk cita rasa produk. Bahan pengemasan menggunakan Plastik Polyetilen (Kris) $(28 \times 40 \mathrm{~cm})$. Bahan yang digunakan untuk uji TPC meliputi Plate Count Agar, alkohol 70\%, kapas, Potassium Dihydrogen Phosphate, Butterfield's Phosphate Buffered, $\mathrm{NaOH}$, Akuades.

darah yang telah dicuci ditampung didalam keranjang. Kemudian kerang darah ditimbang sebanyak $8 \mathrm{~kg}$ dan dilakukan perebusan, kerang direbus selama 20 menit dan ditambahkan air sebanyak 4 liter dan dilarutkan garam sebanyak $80 \mathrm{~g}$. Kemudian setelah selesai pererebus lalu diadakan pemisahan daging kerang dan cangkangnya, kemudian daging kerang disimpan dalam wadah bersih. Setelah itu, daging kerang ditusuk, dalam 1 tusukan berisi 8 daging kerang dan panjang tusukan $\pm 20 \mathrm{~cm}$, lalu dilakukan pengasapan selama 120 menit dengan suhu $60-70^{\circ} \mathrm{C}$, menggunakan drum pengasapan setelah pengasapan kemudian dilakukan pendinginan dan disimpan pada wadah yang bersih selama 6 jam.

Kemudian dilakukan proses pengemasan yang terdiri dari 2 teknik pengemasan dengan vakum (V1) dan non vakum (V2) dan kemudian dilakukan proses penyimpanan di suhu ruang yang terdiri dari 3 ulangan yaitu 2 hari (L1), 4 hari (L2), 6 hari (L3).

\section{Analisis Data}

Data yang diperoleh dianalisis menggunakan analisis ragam (ANOVA), jika hasil analisis menunjukan beda nyata maka dilakukan uji Duncan's Multiple Range Test (DMRT) untuk mengetahui beda nyata antar perlakuan dengan tingkat kepercayaan $95 \%(\alpha=0,05)$. 
ISSN : 2621 - 1475

Pengaruh Perbandingan Rumput Laut (Dawista et al.,)

\section{Uji Organoleptik}

\section{HASIL DAN PEMBAHASAN}

Nilai rerata uji organoleptik tiap perlakuan terhadap para meter kenampakan, aroma, rasa dan tekstur dapat dilihat pada Tabel 1 , sebagai berikut :

Tabel 1. Nilai rerata tertinggi produk kerang darah asap yang dikemas vakum dan non vakum penyimpanan waktu yang berbeda

\begin{tabular}{ccccc}
\hline Perlakuan & Kenampakan & Aroma & Rasa & Tekstur \\
\hline V1L1 & $7,62^{\mathrm{b}}$ & $7,64^{\mathrm{d}}$ & $7,93^{\mathrm{d}}$ & $7,42^{\mathrm{c}}$ \\
V2L1 & $6,69^{\mathrm{b}}$ & $7,31^{\mathrm{c}}$ & $7,49^{\mathrm{d}}$ & $7,24^{\mathrm{b}}$ \\
V1L2 & $6,58^{\mathrm{b}}$ & $7,11^{\mathrm{b}}$ & $7,04^{\mathrm{c}}$ & $6,82^{\mathrm{b}}$ \\
V2L2 & $6,06^{\mathrm{a}}$ & $6,69^{\mathrm{b}}$ & $6,03^{\mathrm{b}}$ & $6,03^{\mathrm{a}}$ \\
V1L3 & $5,64^{\mathrm{a}}$ & $6,01^{\mathrm{a}}$ & $5,89^{\mathrm{b}}$ & $5,80^{\mathrm{a}}$ \\
V2L3 & $4,69^{\mathrm{a}}$ & $5,44^{\mathrm{a}}$ & $4,92^{\mathrm{a}}$ & $4,84^{\mathrm{a}}$ \\
\hline
\end{tabular}

Keterangan : Teknik pengemasan vakum dan lama penyimpanan V1L1=(2 hari),V1L2=(4 hari),V1L3=(6hari)teknik pengemasan non vakum dan lama penyimpanan V2L1=(2 hari),V2L2=(4 hari), V2L3=(6 hari).

\section{Uji Kimia}

Nilai rerata uji kimia tiap perlakuan terhadap patameter kadar air dan TPC (Total Bakteri) dapat dilihat pada Tabel 2, sebagai berikut :

Tabel 2. Nilai rerata tertinggi produk kerang darah asap yang dikemas vakum dan non vakum penyimpanan waktu yang berbeda.

\begin{tabular}{ccc}
\hline Perlakuan & Kadar Air $(\%)$ & TPC / Total Bakteri (CFU/ml) \\
\hline V1L1 & 45,26 & $1,10 \times 10^{3}$ \\
V2L1 & 51,12 & $1,38 \times 10^{3}$ \\
V1L2 & 45,92 & $1,12 \times 10^{3}$ \\
V2L2 & 61,72 & $4,57 \times 10^{3}$ \\
V1L3 & 50,66 & $7,10 \times 10^{3}$ \\
V2L3 & 63,65 & $2,21 \times 10^{4}$ \\
Keterangan : & Teknik pengemasan vakum dan lama penyimpanan V1L1=(2 hari),V1L2=(4 hari),V1L3=(6hari)teknik pengemasan \\
& non vakum dan lama penyimpanan V2L1=(2 hari),V2L2=(4 hari), V2L3=(6 hari).
\end{tabular}

Nilai rerata uji kimia terhadap patameter Analisis PAH (Polycyclic Aromatic Hydrocarbon) dapat dilihat pada Tabel 3, sebagai berikut

Tabel 3. Nilai rerata tertinggi produk kerang darah asap yang dikemas vakum dan non vakum

\begin{tabular}{|c|c|c|c|}
\hline \multirow{3}{*}{ No } & \multirow{3}{*}{ Parameter Uji } & \multicolumn{2}{|c|}{ Teknik pengemasan berbeda } \\
\hline & & V1 (Pengemasan vakum) & V2 (Pengemasan non vakum) \\
\hline & & \multicolumn{2}{|c|}{ ppm } \\
\hline 1 & Naphtalen & 77,46 & 95,74 \\
\hline 2 & Acenaphtalen & $<0,53$ & $<0,53$ \\
\hline 3 & Phenanthrene & $<0,38$ & $<0,38$ \\
\hline 4 & Pyrene & $<4,37$ & $<4,37$ \\
\hline 5 & Benzo@antracene & $<9,08$ & $<9,08$ \\
\hline 6 & Benzo(a)pyrene & $<0,51$ & $<0,51$ \\
\hline
\end{tabular}




\section{Uji Organoleptik}

\section{a. Kenampakan}

Penelitian ini menunjukkan bahwa, selama waktu penyimpanan dan jenis kemasan yang berbeda nilai uji kenampakan mengalami penurunan. Penurunan parameter kenampakan paling cepat terjadi pada perlakuan kemasan non vakum. Dikarenakan adanya udara dalam kemasan, maka dapat memicu naiknya kadar air dan dapat mempermudah pertumbuhan bakteri. Menurut Winarno (2002), penurunan kenampakan dikarenakan aktivitas bakteri. Sedangkan perlakuan menggunakan kemasan vakum mampu memperlambat penurunan parameter kenampakan.

Hal ini dikarenakan tidak adanya udara dalam kemasan maka pertumbuhan bakteri akan melambat. Adapun faktor yang dapat mempertahankan produk kerang darah asap adalah senyawa fenol dalam asap tempurun dan sabut kelapa yang menempel pada permukaan kerang darah. Senyawa fenol juga memberikan kontribusi,yaitu kenampakan mengkilap dan warna kecoklatan (Pratama, 2011). Pengemasan pada kerang darah asap memberikan pengaruh terhadap kenampakan kerang darah asap olahan, karena pengemasan melindungi bahan sehingga memperlambat penurunan mutu.

Berdasarkan hasil parameter kenampakan kerang darah asap yang dikemas vakum dan non dikemas vakum dengan lama penyimpanan 6 hari, nilai organoleptik dari parameter kenampakan suda tidak disukai panalis, hanya pada penyimpanan 2 hari produk baik yang dikemas vakum dan non vakum menurut pengamatan panelis produk masih sangat disukai,

yang sejalan dengan penelitian Paputungan et al. (2015) y ang menyatakan bahwa semakin lama penyimpanan maka nilai produk semakin menurun. Dari data yang didapat menunjukkan bahwa penyimpanan dengan cara divakum dapat mempertahankan nilai kenampakan tetapi masih kurang maksimal karena produk disimpan pada suhu ruang yang suhunya kurang terkontrol.

\section{b. Aroma}

Selama penyimpanan berlangsung, nilai organoleptik dari parameter aroma mengalami penurunan. Penurunan parameter aroma paling cepat terjadi pada perlakuan kemasan non vakum. Dikarenakan adanya udara dalam kemasan, maka dapat memicu naiknya kadar air dan dapat mempermudah pertumbuhan mikroganisme selain itu juga terjadi perubahan aroma menjadi beraroma tengik. Widiastuti (2007) menyatakan kehadiran mikroganisme pada ikan mengakibatkan perubahan aroma. Sedangkan perlakuan menggunakan kemasan vakum mampu memperlambat penurunan parameter aroma. Hal ini dikarenakan tidak adanya udara dalam kemasan maka pertumbuhan mikroganisme akan melambat.

Berdasarkan nilai organoleptik aroma yang ada di atas produk yang dikemas vakum dan tidak dikemas vakum dengan lama penyimpanan 6 hari, nilai sensori dari parameter aroma suda tidak disukai panelis, pada penyimpanan 2 hari produk baik yang dikemas vakum dan non vakum diminati panelis Masi sangat di sukai karena aroma asap masih tercium dan produk masih baik, yang sejalan dengan penelitian Kaiang et al. (2016) yang menyata kan bahwa kurangnya nilai aroma produk ikan asap yang di kemas vakum dan non vakum selama penyimpanan diduga sebagai akibat pelepasan senyawa-senyawa lain yang tidak dikehendaki yang ikut bersama-sama di dalam asap.

\section{c. Rasa}

Penelitian ini menunjukkan bahwa, selama waktu penyimpanan berlangsung, nilai organoleptik rasa mengalami penurunan. Penurunan parameter rasa paling cepat terjadi pada perlakuan kemasan non vakum. Dikarenakan adanya udara dalam kemasan, maka dapat memicu naiknya kadar air dapat mempermudah pertumbuhan mikroganisme. Widiastuti (2007) menyatakan kehadiran mikroganisme pada ikan mengakibatkan perubahan rasa. Sedangkan perlakuan menggunakan kemasan vakum mampu memperlambat penurunan parameter rasa. Hal ini dikarenakan tidak adanya udara dalam 
kemasan maka kadar air minim dalam kemasan dan juga pertumbuhan mikroganisme akan melambat dan kandungan fisik dan kimia tidak cepat berubah. Adapun faktor lain lama penyimpanan dapat merubah cita rasa kerang darah asap . Menurut Winarno (2002) lama penyimpanan cenderung dapat meningkatkan kadar air sehingga rasa pada makanan menjadi tidak enak dan tidak diterima oleh konsumen.

Berdasarkan hasil sensori rasa yang ada di atas produk yang dikemas vakum dan tidak dikemas vakum dengan lama penyimpanan 6 hari, nilai sensori rasa suda tidak di suka oleh panelis, pada penyimpanan 2 hari produk baik yang dikemas vakum dan non vakum yang diminati panelis masih sangat di sukai.

Menurut Angela et al. (2015) melaporkan bahwa rasa yang tidak enak disebabkan oleh factor lingkungan yang mendukung pertumbuhan mikroba selama penyimpanan misalnya kadar air dan suhu sehingga tumbuhnya mikroba akan merusak daging.

\section{d. Tekstur}

Penelitian ini menunjukkan bahwa, selama waktu penyimpanan berlangsung, nilai sensori tekstur mengalami penurunan. Penurunan parameter tekstur paling cepat terjadi pada perlakuan kemasan non vakum. Dikarenakan adanya udara dalam kemasan, maka dapat memicu naiknya kadar air. Menurut Purnomo (1995) kadar air yang tinggi menyebabkan tekstur pada bahan pangan menjadi lunak. Tingginya kadar air juga dapat mempermudah pertumbuhan mikroganisme.. Hal ini dikarenakan tidak adanya udara dalam kemasan maka kadar air minim dalam kemasan dan juga pertumbuhan mikroganisme akan melambat.

Berdasarkan nilai sensori aroma yang ada di atas produk yang dikemas vakum dan tidak dikemas vakum dengan lama penyimpanan 6 hari, nilai organoleptik dari parameter tekstur suda mulai tidak di sukai oleh panelis, pada penyimpanan 2 hari produk baik yang dikemas vakum dan non vakum yang diminati panelis masih di sukai oleh palesis.

Menurut Wibowo (2000), melaporkan bahwa tekstur ikan asap yang baik yaitu tekstur yang kompak, cukup elastis, tidak lembek dan tidak lent. Selanjutnya dinyatakan bahwa pembentukkan tekstur ikan asap dipengaruhi oleh peranan formaldehid yang terkandung dalam asap.

\section{Uji kimia}

\section{a. Analisis kadar air}

Hasil penelitian menunjukan bahwa semakin lama masa simpan baik untuk kerang darah asap yang dikemas vakum maupun non vakum nilai kadar air kerang darah asap tersebut akan semakin meningkat. Dilihat pada kerang darah asap yang dikemasan vakum lebih sedikit kadar airnya, dibandingkan dengan kerang darah asap yang dikemas non vakum lebih tinggi. Hal ini disebabkan karena meningkatnya aktifitas mikroorganisme yang terdapat pada kerang darah asap selama penyimpanan yang mengakibatkan peningkatan laju respirasi serta peningkatan hasil pembentukan air bebas. Hal ini juga disampaikan oleh Winarno (2004) mikroorganisme dapat menyebabkan terurainya struktur protein pada bahan pangan sehingga menyebabkan terlepasnya air terikat pada jaringan otot.

Kerang darah asap yang dikemas vakum masih memenuhi standar SNI baik yang disimpan pada waktu 2,4 dan 6 hari sedangkan kerang darah yang dikemas non vakum 2 hari masih memenuhi stadar SNI sedangkan pada penyimpanan waktu 4 dan 6 hari telah melebihi atau tidak memenuhi standar SNI. SNI mensyaratkan kadar air ikan asap maksimal 60\% (Badan Standarisasi Nasional, 2013). Diduga tingginya kadar air pada kemasan non vakum pada penyimpanan 4 dan 6 hari karena pengemasan non vakum masih memiliki udarah dalam kemasan oleh karenanya kadar air akan tinggi dibandingkan dengan pengemasan vakum.

menurut (Agus et al., 2014) menyatakan bahwa tingginya kadar air dalam ikan asap dapat disebabkan kurangnya waktu pemanasan dan penirisan. Kadar air dapat mempengaruhi umur simpan ikan asap karena air merupakan salah satu factor yang diperlukan mikroorganisme untuk perkembangbiakannya. Semakin tinggi kadar air dapat menyebabkan produk semakin mudah rusak oleh mikroorganisme.

\section{b. Analisis Total Bakteri (TPC)}

Hasil pengujian total bakteri pada kerang darah asap yang dikemas vakum dan non vakum pada waktu 
penyimpanan berbeda dalam suhu ruang. Jumlah mikroba dalam bahan pangan mempengaruhi cepat lambatnya kerusakan suatu bahan pangan. Menurut Hadiwiyoto (1994), cepat lambatnya kerusakan hasil perikanan secara mikrobiologis tergantung pada kecepatan pertumbuhan mikroba yang ada terutama bakteri pembusuk. Pertumbuhan bakteri pada umumnya diartikan sebagai kenaikan jumlah konstituen dalam sel atau massanya, kemudian diikuti oleh perbayakan sel sehingga jumlah sel menjadi bertambah.

Semakin tinggi jumlah bateri terhadap suatu produk maka semakin buruk atau berbahaya bila melebihi batas yang ditentukan SNI jika dikonsumsi. Berdasarkan hasil analisi total bakteri kerang darah asap yang dikemas non vakum lebih tinggi jumlah bakteri yang tumbuh dibanding pengemasan vakum. Faktor yang mempengaruhi pengemasan vakum lebih rendah dibandingkan pengemasan non vakum. Hal ini diduga karena pengemasan vakum tidak ada udarah dalam kemasan maka dapat mencegah pertumbuhan bateri aerob.

Berdasarkan SNI No. 2725:2013, total mikroba (angka lempeng total) ikan asap tidak boleh lebih dari $5 \times 10^{4} \mathrm{cfu} / \mathrm{ml}$. Jika total bakterinya melebihi batas maksimal yang ditentukan SNI, ikan asap dinyatakan tidak aman untuk dikonsumsi. Berdasarkan hasil analisis bakteri kerang darah asap yang tertinggi yaitu dikemas non vakum pada penyimpanan hari ke 6 V2L3 yaitu 2,21 $\quad x \quad 10^{4} \mathrm{CFU} / \mathrm{ml}$ masih memenuhi satandar maksimal yang ditentuk an SNI atau masih aman dikonsumsi, yang sejalan dengan penelitian Angela et al. (2015) yang menyat akan bahwa produk yang dikemas vakum lebih baik dibandik produk yang tidak dikemas vakum selama proses penyimpanan berlangsung.

\section{c. Analisis PAH (Polycyclic Aromatic Hydrocarb}

on)

Hasil penelitian menunjukan bahwa kandungan benzo( $\alpha)$ pyrene yang terdapat pada pengemasan vakum (V1) yaitu $<0,51$ ppm sedangkan untuk pada pengemasan non vakum (V2) sama dengan pengemasan vakum yaitu $<0,51 \mathrm{ppm}$. Nilai tersebut batas maksimal terkecil yang dideteksi oleh metode kromatrografi gas yang digunakan. Menurut Syahrir et al. (2015). Standar tersebut sama dengan standar SNI yaitu 0,005 ppm Ghazali et al. (2014). Adapun sampel dengan nilai benzo(a)pyrene sama antara pengemasan vakum dan pengemasan non vakum adalah $<0,51$ ppm. Namun meskipun demikin niai tersebut juga masih melebihi batas standar yang ditetapkan. $P A H$ perlu selalu dipantau keberadaannya, karena dapat menyebabkan mutasi genetik dan menimbulkan penyakit kanker Syahrir et al. (2015) $P A H$ termasuk golongan zat kimia yang bersifat genotoksik dan memberikan efek dapat membentuk ikatan kovalen dengan basa dari DNA (Ghazali, 2014). PAH memiliki gugus elektrofil yang akan membentuk ikatan kovalen dengan gugus nukleofilik seperti asam amino, sulfohidril dan gugus hidroksil pada molekul lain Swastawati et al. (2013). Menurut (Doe, 1998), benzo(a)pyrene dianggap sebagai indikator senyawa yang bersifat karsinogen pada makanan asap.

Tinggginya kandungan benzo(a)pyrene pada bahan bakar cangkang dan sabut kelapa diduga dipengaruhi oleh proses pengolahan seperti suhu pembakaran, waktu pengasapan, ketebalan asap, aliran udara, bahan baku dan kondisi pengasapan lainnya. Kandungan $P A H$ akan meningkat seiring dengan meningkatnya suhu (Whittle dan Howgate, 2000). Berdasarkan penelitian Hadiwiyoto et al., (2000). metoda pengasapan panas atau secara tradisional, menyebabkan kandungan Benzo(a)Pyrene lebih tinggi.

Dalam penelitian (Agustine, 2008) mendapatkan kadar rerata $P A H$ dalam kerang hijau yang berukuran 1,0 -1,5 cm di Teluk Jakarta sebesar 167,253 ppm. Achayani (2011) mendapatkan kadar PAH dalam tubuh ikan Nomei (Horpodon nehereus) di Perairan Tarakan berkisar antara 1.582 - 2.747 ng/g, dan Lukitaningsih dan Ari (2010) mendapatkan kadar PAH dalam tubuh ikan yang berasal dari laut selatan daerah Baron Yogyakarta yakni ikan petek (Chrorinomus lyson) berkisar antara 0,9 - 310,9 ng/g, dan ikan Kuniran (Upeneus moluccensis) berkisar antara 1,9 $1072,5 \mathrm{ng} / \mathrm{g}$. 


\section{KESIMPULAN}

Berdasarkan hasil penelitian dan pembahasan, maka dapat disimpulkan sebagai berikut

1. Terdapat pengaruh faktor pengemasan vakum dan non vakum pada lama waktu penyimpanan pada kerang darah asap terhadap uji organoleptik yaitu kenampakan, aroma dan rasa berpengaruh sangat nyata untuk tekstur berpengaruh nyata. Untuk nilai tertinggi terdapat pada perlakuan V1L1 dan nilai terenda terdapat pada perlakuan V2L3.

2. Terdapat pengaruh pengaruh faktor pengemasan vakum dan non vakum pada lama waktu penyimpanan terhadap uji total bakteri (TPC) kerang darah asap .nilai terbaik terdapat pada

\section{DAFTAR PUSTAKA}

Achyani, R. 2011. Karaktersitik Polisiklik Aromatik Hidrokarbon (PAH) di Air Laut dan Sedimen serta Akumulasinya pada Tubuh Ikan Nomei (Horpodon nehereus) di Perairan Tarakan. Thesis,PPS IPB,Bogor, 110 hal.

Agus, T. S. W., Fronthea, S., dan Apri, D. A. (2014). kualitas ikan pari (dasyatis sp ) asap yang diolah dengan ketinggian tungku dan suhu yang berbeda Jurnal Pengolahan dan Bioteknologi Hasil Perikanan vol.(3).(1)

Agustine, D. 2008. Akumulasi Hidrokarbon Aromatik Polisiklik (PAH) daam Kerang Hijau (Verna Viridis L) di Perairan Kamal Muara, Teluk Jakarta.Skripsi: FPIK IPB 115 hal.

Angela, G. C., Mentan, F., dan Sanger, C.(2015). kajian mutu ikan cakalang (katsuwonus pelamis, L.) asap dari tempat pengasapan desa girian atas yang di kemas vakum dan non vakum selam penyimpanan dingin jurnal media teknologi hasil perikanan vol.(3).(2)

Doe, P.E., 1998. Fish Drying and Smoking: Production and Quality. Pennsylvania: Technomic Publication. $245 \mathrm{hlm}$.

Ferial, E. W., E. Soekandarsih., M.S. Hassan, dan A. Muchlis., 2011. Potensi Kerang Darah A.granosa sebagai Terapi Perbaikan Kualitas SpermatozoidManusia. Jurusan Biologi. Fakultas Matematika dan IImu Pengetahuan Alam. Universitas Hasanuddin. Makassar. perlakuan V1L1 dengan nilai $1,1 \times 10^{3} \mathrm{CFU} / \mathrm{ml}$, sedangkan nilai tertinggi terdapat pada perlakuan V2L3 dengan nilai 2,21 x 104 CFU/ ml masih aman dikosumsi.

3. Terdapat pengaruh faktor pengemasan vakum dan non pada lama waktu penyimpaan terhadap uji kimia kerang darah asap yaitu uji kadar air nilai terbaik terdapat pada perlakuan V1L1 dengan nilai $45,26 \%$ untuk nilai tertinggi terdapat perlakuan V2L3 dengan nilai $63,65 \%$ sementara pada uji Polycyclic Aromatic Hydrocarbon (Benzo (a) phyrene) memiliki nilai yang sama antara pengemasan vakum dan non vakum yaitu $<0,51$ ppm.

Ghazali, R.R., Swastawati, F., dan Ramadhon. 2014. Analisa Tingkat Keamanan Ikan Manyung (Arius thalassinus) Asap Yang Diolah Dengan Metode Pengasapan Berbeda. Program Studi Teknologi Hasil Perikanan, Jurusan Perikanan, Fakultas Perikanan dan IImu Kelautan. Universitas Diponegoro. Semarang

Hadiwiyoto, S. 1994. Teknologi Pengolahan Hasil Perikanan. Penerbit Liberty, Yogyakarta.

Hadiwiyoto, Darmadji, P., dan Purwasari, S.R. 2000. Perbandingan Pengasapan Panas dan Penggunaan Asap Cair pada Pengolahan Ikan : TinjauanKandungan Benzopiren, Fenol dan Sifat Organoleptik Ikan Asap.Agritech, Vol. 20 No. 1, 14-19 hlm.

Heruwati, E.S. 2002. Pengolahan ikan secara tradisional: prospek dan peluang pengembangan. Pusat riset pengolahan produk dan sosial ekonomi kelautandan perikanan, Jakarta.

Jay, 1996. Modern Food Microbiology 4 th edition.New York : D Von Nostrand Company. Kaiang, D.B.,Montolalu, L.A.D.Y., dan Montolalu, R.I. ,(2016). Kajian Mutu Ikan Tongkol (Euthynnu $s$ Affinsi)Asap Utuh yang Dikemas Vakum dan Non Vakum Selama 2 Hari Penyimpanan pada Suhu Kamar Jurnal Pengolahan dan Bioteknologi Hasil Perikanan vol.(4).(2)

Lukitaningsih, E., dan Ari, S. 2010. Bioakumulasi Senyawa Polisiklik Aromatik Hidrokarbon 
dalam Plankton, Ganggang, dan Ikan. Di Perairan Laut Selatan. M. Farmasi Indon. 21: 18-26

Paputungan, T.S., Wonggo, D.,dan Damongilala, L.J . 2015. Kajian Mutu Ikan Cakalang (Katsuwon us Pelamis

L.) Asap Utuh yang Dikemas Vakum dan Non Vakaum Selama Proses Penyimpanan pada Suhu Ruang jurnal media teknologi hasil perikanan vol.(3).(2).

Pratama, R. I., 2011. Karakteristik flavor beberapa jenis ikan asap di Indonesia. (Tesis) Pascasarjana IPB. Bogor.

Purnomo, H., 1995 Aktivitas Air dan Peranannya dalam pengawetan Pangan. UI Press. Malang.

SNI. 2013.Batas Kadar Air pada Produk Ikan Asap . SNI No. 012725 2013. Badan Standarisasi Nasional

Swastawati, F., Titi, S.u., Tri, W.A. dan Putut, H.R. 2013. Karakteristik kualitas ikan asap yang diproses menggunakan metode dan jenis ikan berbeda.Jurnal Aplikasi Teknologi Pangan 2(3):126-132.

Syahrir, M., Aprilita, N. H dan Nuryono. 2015. Validasi Metode Analisis Polisiklik Aromatik Hidrokarbon (PAH) dalam Sedimen di Sekitar Pantai Makassar.Jurusan Kimia. Fakultas MIPA. Universitas Gadjah Mada.

Whittle KJ, dan Howgate P. 2000. Glossary of Fish Technology Terms. Prepared under contract to the Fisheries Industries Division of the Food andAgriculture Organization of the United Nations. terhubung berkala.. pdf, 4 Maret 2010.

Wibowo, 2000. Industri pengasapan ikan. Penabar Swadaya. Jakarta. Skripsi.

Widiastuti, I.M.2007. Sanitasi dan Mutu Kesegaran Ikan Kosumsi pada Pasar Tradisional Di Kotamadya Palu. Jurnal. Agroland 14 (1):77-81 ISSN: 0854-641X.

Winarno, F.G. 2002. Kimia Pangan dan Gizi. PT.Gramedia Pustaka Utama: Jakarta. 2004. Kimia Pangan dan Gizi. Jakarta: Penerbit PT. Gramedia Pustaka Utama. 